Article

\title{
Housing Preferences of Seniors and Pre-Senior Citizens in Poland-A Case Study
}

\author{
Anna Jancz $@$ and Radoslaw Trojanek * \\ Department of Microeconomics, Institute of Economics, Poznań University of Economics and Business, \\ Al. Niepodległości 10, 61-875 Poznań, Poland; anna.jancz@ue.poznan.pl \\ * Correspondence: radoslaw.trojanek@ue.poznan.pl
}

Received: 21 April 2020; Accepted: 2 June 2020; Published: 4 June 2020

check for updates

\begin{abstract}
This article identifies and compares the housing preferences of seniors and pre-senior citizens in Poland. In addition, the attitude of residents of large cities in the Wielkopolskie Voivodeship towards senior citizens' housing was determined. Surveys were conducted in the two largest cities of this region. The influence of the potential behaviors of this group of society on the development of housing was also examined. Results showed that differentiation of housing preferences was visible primarily when choosing the type of development and size of the dwelling. Seniors preferred smaller units in multi-family housing construction. Pre-senior citizens, on the other hand, were more likely to think about living in a single-family house. The location of a new dwelling was also important. Seniors, more often than people aged 50-59, chose a location in the city center. Pre-senior citizens, in contrast, more often decided to live in a rural area or outside the city center. Moreover, the attitude of seniors towards senior citizens' housing is undecided, which may indicate that many people may change their housing preferences in the future and decide to move.
\end{abstract}

Keywords: housing preferences; senior citizen; senior housing

\section{Introduction}

For several decades, European society, including that of Poland, has been accompanied by the phenomenon of population ageing [1-8]. This process is manifested by changes in the age structure of the overall population as a continuous increase in the proportion of older people and a decrease in the proportion of people of working age. The causes of the ageing process should be seen in relation to the changes taking place in three spheres: fertility, mortality and migration. Research attention has been drawn to the low birth rate and higher life expectancy in the developed and developing countries of the EU [9-11].

In 2018, the youngest inhabitants (0-14 years old) accounted for $15.6 \%$ of the population the European Union (EU), while people of working age (15-64 years old) accounted for $64.7 \%$ of the population. For the same period, seniors (people over 65) represented a share of $19.7 \%$ of the EU population. The EU country with the oldest demographic is Italy, in which seniors accounted for $22.6 \%$ of the national population in 2018 , followed by Greece, with a slightly lower share of $21.8 \%$. Among the EU Member States, Ireland has the lowest share of senior citizens (13.8\% of the country's population). In Poland, the share of people over 65 years old in 2018 was 17.1\%.

Eurostat's projection of the age structure for 2018-2100 indicates that the ageing of the population will continue. By 2100, it is estimated that people over 65 years of age in EU countries will account for $31.3 \%$ of the total EU population. This age group will be characterized by the ageing of the elderly. It is likely that the proportion of people over 80 by 2100 compared to 2018 will increase 2.5 times. This follows the entry into retirement age of the post-war baby boomers (Eurostat, 2019). 
In Poland, a phenomenon accompanying the ageing process is the tearing of family ties, which results from the disappearance of the multi-generational family form. The elderly increasingly do not live with their children or grandchildren. In such a situation, family members stop taking care of seniors. Older people become lonely in everyday life [12,13].

As a result of these developments, there is a need to develop social policies targeted at the elderly. In Poland, the first activities are being carried out concerning the introduction of seniority policies and the orientation of the economy towards the elderly (i.e., the silver economy). The introduced facilities involve various industries, including housing for the elderly. An older person can become an essential player in the real estate market. Therefore, it seems important to know the housing preferences of this age group in order to adapt the market to their housing needs.

The current study addresses the problem of examining housing preferences of people in the pre-senior (aged 50-59) and senior (people over 60) age groups, and examines residents' attitudes towards senior citizens' housing, in large cities (over 100,000 inhabitants) in the Wielkopolskie Voivodeship. The article poses two hypotheses:

Hypotheses 1 (H1). The housing preferences of seniors will be characterized by a lower propensity for migrating behavior than those of pre-senior citizens in Polish socio-economic environment.

Hypotheses 2 (H2). The attitude of the residents of large cities will be positive in relation to senior citizens' housing.

Research on the housing preferences of older people should be repeated. To date, senior generations have lived with the idea of "ageing in place". Today, seniors often live in flats that are not adapted to their needs, which manifests itself primarily in the inadequacy of the housing stock and dwellings in which older people move (e.g., lack of lifts, handles on stairs, door thresholds). In addition, older people often live alone in a large apartment, which is associated with higher apartment operating costs. The attachment to apartment ownership is currently of paramount importance for Polish seniors.

\section{Overview of Existing Studies}

The issue of the housing preferences of elderly people is relatively rarely discussed in the Polish literature. The most up-to-date nationwide information on housing preferences of seniors comes from two studies: "Senior housing in Poland. Prospects for development" [14] and "Expertise on examining the housing needs of seniors and indicating significant problems and deficits in the area of senior housing-2017". The latter document was key in updating housing policy in Poland, including the place of the elderly. Moreover, the housing situation of seniors was described in studies prepared by the Central Statistical Office (CSO) [15] and Public Opinion Research Center (PORC) [16]. Basic cyclical information on the housing conditions of seniors is provided by the CSO as part of the four-year census. Issues concerning the housing situation and housing needs of seniors are also addressed in research of a local nature. There have also been publications which attempt to systematize the types of housing construction for seniors in Poland.

Some recent research on the identification of housing needs was prepared by Przybyła et al. [17] and Iwański et al. [18]. They used survey research in order to identify the housing preferences of the respondents. In the first study, the authors examined the preferences of potential purchasers of apartments for seniors and the desire of seniors to switch their place of residence so as to consider an apartment suited to their mobility needs. The latter study aimed to evaluate elderly people's housing preferences and to investigate the approaches of selected municipalities in fulfilling the housing needs of seniors. In turn, Tanaś et al. (2019) examined the revealed preferences of seniors who had recently purchased a dwelling basing on the information from transactions in Poznań. Szukalski [10] and Zrałek [19] attempted, in turn, to determine the direction of adaptation of the residential market to the needs of older people, and the associated challenges. Kłobukowska [20] indicated that housing policy in the country may not respond to the housing needs of the elderly, whose share is constantly growing. The results of Niezabitowski's [21] research draw attention to the multiplicity of reasons for senior citizens' 
attachment to their current place of residence, followed by their reluctance to change their residence. The author points out that there is a need for organizational and architectural urbanization solutions, which will provide assistance to seniors in their current place of residence. Jancz [22] studied the satisfaction of seniors who have changed their place of residence to an independent apartment designed with architectural facilities for seniors. Burzyńska and Malinin [23] considered how seniors' apartments should be designed. Moreover, Dudek-Mańkowska [24], Magdziak [25], Pytel [26], and Labus [27] discussed available solutions in the field of senior housing. Magdziak [25] described widely developed housing for seniors in the United States. She distinguished several types of housing, depending on the degree of independence and psychophysical fitness of the seniors. Labus [27] analyzed the types of flats available in Poland for senior citizens, indicating that the offering of flats for senior citizens should be diversified due to the different characteristics of older people. The author pointed to an undeveloped form of senior housing in Poland, which is popular abroad, e.g., intergenerational houses in Germany. Pytel [26] drew up a typology of the types of flats for senior citizens in Poland and examined the impact of senior migration on urban planning. Dudek-Mańkowska [24] also discussed solutions available in Poland in the field of senior housing.

In the foreign literature, especially in the United States and Western Europe, study of the housing situation of seniors and their housing preferences began considerably earlier. However, research on the housing situation of senior citizens is still ongoing.

Brecht [28] undertook a comprehensive analysis of the residential market for senior citizens in the United States. Anarde [29] described the housing situation of seniors living in rural areas of the USA. Ismail et al. [30] examined the housing preferences of senior citizens in Malaysia. In the Netherlands, an experiment was carried out in which senior citizens' housing preferences were combined with a parallel senior citizens' housing project based on the best attributes indicated by seniors [31]. In Slovenia, the reluctance of seniors to change their place of residence was highlighted. In a survey of the housing preferences of people over 50 years of age, the types of housing construction for seniors that could potentially be of interest to seniors were identified. It was indicated that seniors and pre-senior citizens often do not know the available housing options and a survey of housing preferences will allow for the adjustment of housing policies to the housing needs of senior citizens [32]. In Germany, the housing preferences of people in pre-retirement age in 10 cities were also studied, with the primary aim of determining whether the respondents considered changing their place of residence in the future or preferred to stay in their current dwelling [33]. The Hillcoat-Nalletamba et al. [34] study attempted to compare the housing needs of senior citizens in France and England, drawing attention to the housing policies of both countries. The introduction of housing solutions was also discussed. Pedersen [35] presented the functioning of co-housing in Denmark, Gu et al. [36] discussed the scale of demand for environmental services in affordable housing communities in a city in China, and van Hoof et al. [37] considered the possibility of designing a smart home for older people. Hwang et al. [38] reviewed the research on the housing situation of seniors in the United States, highlighting four important areas: seniors' behavior and their existing housing preferences, satisfaction with their current location, their housing policies, and the design features of the available housing stock. Carroll and Qualls [39] looked at the psychological aspect of the change of residence, discussing the stages of adaptation to such a change. Glasby et al. [40] raised the issue of the consequences of the closure of an institution where elderly people lived.

The motive for addressing the issue considered in the current study is a previous gap in the national literature on housing preferences for seniors in Poland. The research conducted to date has also failed to take into account the characteristics of seniors concerning, among other factors, their place of residence.

\section{Silver Economy and Housing for Seniors}

The process of an ageing society has created the need to develop a new sector in the economy. This is the so-called "silver economy". The concept of the "silver economy" originates from Japan 
and its basic assumption was to focus on the needs of seniors [40-42]. The idea of the silver economy assumes the creation of products and services for people over 50 and the implementation of trade agreements and contracts between economic entities that will help to adapt to the employment of increasingly older people $[43,44]$.

The idea of a silver economy in Europe was first considered in 2005 in Germany as a joint initiative of European regions. It was then proposed that Europe's demographic situation should be regarded as a challenge or an opportunity for development and not as a potential threat. To this end, measures were introduced that would improve the quality of life of older people, stimulate economic activity for growth, create jobs and cohesion, and support and integrate the various regions of the European Union. The importance was recognized of making the public aware of the need to focus the economy on older people. Failure to take action in this area may have negative consequences, particularly in the economic field. The development of the silver economy is possible only in the case of cooperation of many entities, including governmental administration of countries, politicians, entrepreneurs, economic partners, and non-governmental entities [45].

The silver economy includes the construction of housing for seniors [46]. This is a type of housing in which the needs of the elderly play a special role. This type of housing guarantees seniors an appropriate standard of living space and building in terms of architectural facilities and services, particularly in relation to care, medical services, and rehabilitation.

The concept of residential housing offered exclusively to the elderly was developed in the United States. Its beginning dates to the 1950s. It is therefore a relatively new segment of the real estate market. Currently, in the United States, the housing offering for the elderly is extensive $[24,25,28,47-50]$.

There are few such projects in Poland. As much of the choice of seniors regarding the place of residence relates to preferences, it is important that there are different alternative place of residence options from which to choose $[14,24,36]$.

The experience of countries abroad in the field of senior citizens' housing shows that different solutions have been adopted in different countries. In Austria, for example, older people have not expressed a desire to change their place of residence. No large-scale construction of housing for senior citizens was undertaken in this situation. The state authorities have invested in a subsidy scheme to help adapt current apartments to residents' needs. In Switzerland, senior citizens' social housing, which is offered by housing associations, has become the preferred option. In Germany, intergenerational houses have become popular, which were created as a result of the government program "Mehrgenerationenhäuser". The construction of buildings and sometimes entire housing estates and towns for senior citizens with access to additional services and with architectural facilities was popular in the United States. Seniors were keen to move to senior citizens' homes because they had access to specialist care, recreational and leisure services, and the company of people of a similar age with similar interests [26-28,35]. In Poland, the direction of senior housing development has not yet been determined.

The housing options available for seniors in Poland are more focused on providing care for seniors who are retired, infirm, or who suffer from senile dementia or other acquired ailments (diseases, illnesses). By delimiting the housing opportunities in Poland and abroad, they can also be divided into state housing (institutional option), non-profit enterprises (social option), and private entrepreneurs and developers (market option) [22,51,52].

Such an interpretation of the first associations with housing for seniors undoubtedly results from the fact that the first assistance for seniors in the field of housing was connected in Poland with running social welfare homes (DPS), which were designed for people who were unable to guarantee independent care, often lonely and sick people, as well as those who were of retirement age.

On the basis of the research conducted to date on the housing preferences of older people and their purchasing behavior, it can be pointed out that the choices of seniors in terms of the type of house they choose from the offering of available senior housing solutions vary depending on the 
age bracket. Different shopping behaviours are demonstrated by people aged 60-69, 70-79, or over 80 (contractual age limits). This is related to diseases or illnesses that are characteristic for given age groups and which limit efficient functioning. The so-called early seniors, representing the first indicated age bracket, are a group of usually active and independent people who often have time to pursue their passions and interests at retirement age. Thus, these people may be interested in the innovative solutions of senior housing provided to the market. The latter age group represents mature seniors who are beginning to notice the first signs of old age in terms of movement, and thus often need some kind of support, which consists of emergency home help or social and health care. A third group of people - the oldest seniors, often representing a group of people who have entered the age of longevity (over 90 years of age) - often depend on their family or their closest relatives to provide home, social, or health care. When they are deprived of such care by the indicated persons, they live in collective nursing homes. In the case of people of retirement age, the choice of such an institution is related to the need to guarantee, first of all, medical care, and not necessarily independent living in modern housing $[17,18,36]$.

It should also be pointed out that seniors in Poland, as in many other countries (e.g., Austria, Germany, Slovenia), are not willing to change their place of residence; they would prefer to stay in the currently occupied housing units, and adapt those residences to their housing needs $[18,32,33,53,54]$.

\section{Research Methodology}

The surveys were conducted in Poznań and Kalisz. These cities are the largest in the Wielkopolskie Voivodeship in terms of population, with over 100,000 inhabitants (as of the end of 2018, CSO). The presented results are part of a representative survey conducted during 2018 and 2019. The research was carried out using a questionnaire that was distributed to respondents over 50 years old during meetings of senior citizens' clubs, at the University of the Third Age classes, and in the street to passers-by. Questionnaires were completed by respondents without assistance but in the presence of the interviewer. Figure 1 presents the steps of the research methodology.

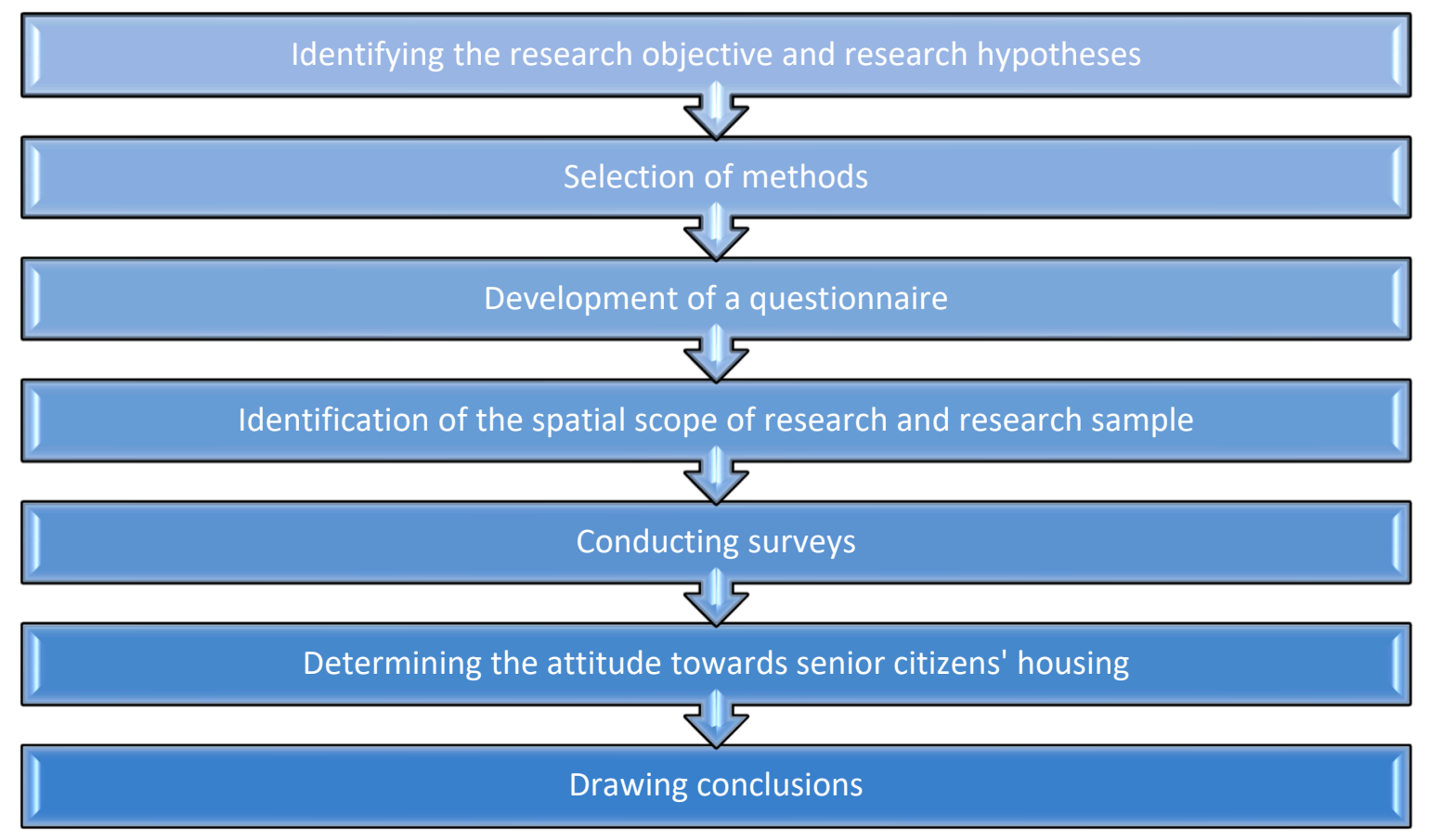

Figure 1. Steps of the research methodology. Source: Own study. 
In the course of the tests carried out at that time, a quota selection for the sample was used (intentional, non-random selection). The research sample with a 3\% forecast error for the inhabitants of the Wielkopolskie Voivodeship over 50 included 1066 questionnaires.

The research sample reflected the structure of the inhabitants of the Wielkopolskie Voivodeship in terms of the number of people living there:

(a) Gender (female/male);

(b) Age (50-54, 55-60, 61-64, 65-69, 70-74, 75 and over);

(c) Residence (town/rural);

(d) The number of inhabitants of the village ( $<5000$ inhabitants, 5-10,000 people, $10-50,000$ people, $50-100,000$ people, $>100,000$ people).

Verification of the conducted study in terms of the distribution of the research sample and population (residents of the Wielkopolskie Voivodeship over 50 years of age) was carried out with the X2 compliance test, and allowed the conclusion that the structure of the sample in terms of gender, age, place of residence, and number of people in the place of residence corresponded to the population structure.

The questionnaires from the largest cities in Wielkopolskie Voivodeship accounted for $19.1 \%$ of the group concerning the number of inhabitants of towns (204 questionnaires). This share reflects the actual structure of the residents of Wielkopolskie Voivodeship aged 50 years and over who lived in cities in Wielkopolskie Voivodeship with over 100,000 inhabitants. The indicated number of questionnaires (204) was further elaborated on in this study.

More than half of the respondents (57\%) of the respondents were women. Taking into account the age of the respondents, it should be pointed out that about $35 \%$ of the respondents were of pre-senior age (50-59 years). Nearly $38 \%$ of the respondents indicated that they were $60-69$ years old and less than $27 \%$ of the respondents indicated that they were over 70 years old. Inhabitants of the analyzed area were characterized by having higher education (almost $63 \%$ of the total number of respondents). In turn, almost one-third of the respondents had secondary education. In terms of professional status, most people indicated that they were retired (almost $60 \%$ of respondents). On the other hand, one-quarter of the respondents worked full-time. Only slightly more than $1 \%$ of the respondents indicated that they were currently unemployed.

Figure 2 presents the structure of respondents' answers to the question concerning the number of people in the household where the respondent lives.

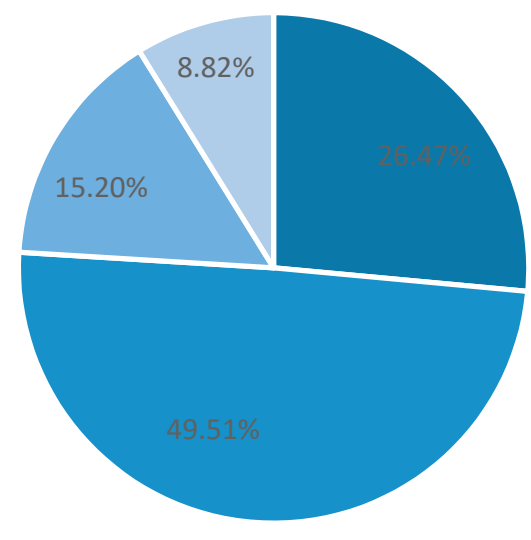

- 1 person - 2 people $\quad 3$ people $\llbracket 4$ and more

Figure 2. Structure of respondents by number of persons in the household. Source: Own study based on the research conducted. 
Almost half of the respondents indicated that they live in a two-person household. Slightly more than $26 \%$ of the respondents replied that they live in a one-person household. The smallest number of people indicated that they live in a large household with four or more household members.

People under 59 indicated that they usually live in two- or three-person households. With age, the number of people in the household decreased. Seniors aged 60-69 more often than older people indicated that they lived in a one-person household, while almost half of the seniors over 70 who took part in the survey indicated that they lived alone.

Another question characterizing the respondents concerned the level of monthly disposable income per person in the household. Most respondents answered that this income was between PLN 1501 and 2500 (almost $42 \%$ of respondents). Nearly one-third of the respondents indicated that the monthly disposable income per person in their household exceeded PLN 3001. The smallest number of people answered that it was up to PLN 1501 per month. With age, the level of income received decreased. People over 70 years of age had the lowest income.

\section{Housing Needs of the Elderly and Senior Citizens}

This subsection presents the results of the survey conducted in relation to the housing needs of the elderly and pre-senior citizens. Figure 3 shows the structure of respondents' answers to the question: Would you like to change your current dwelling and move to another one?

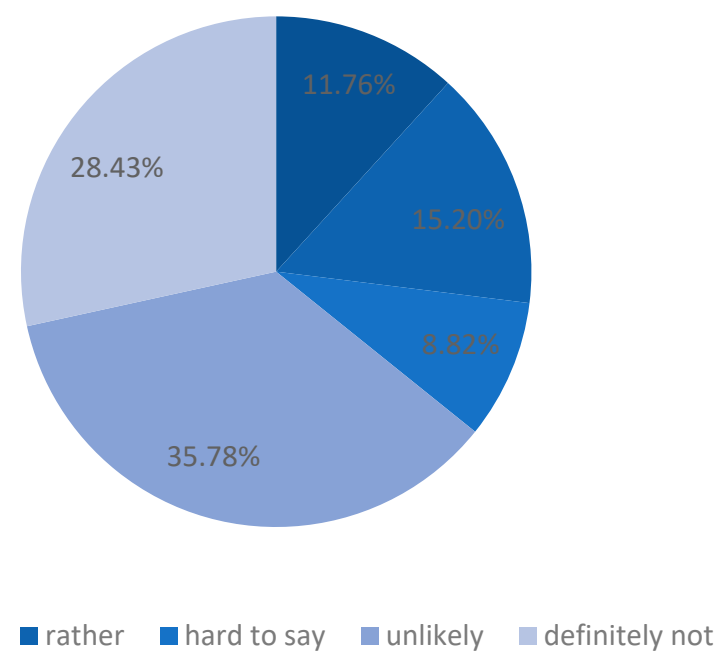

Figure 3. Answers to the question: Would you like to change your existing dwelling and move to another one? Source: Own study based on the research conducted.

A large portion of the respondents did not want to change their place of residence; just over $64 \%$ of the respondents. Nearly $27 \%$ of the respondents replied that they would consider changing their dwelling or certainly would like to change their current occupancy. Among the group interested in a possible change of residence, these were most often people in the 50-59 and 60-69 age ranges. People over 70 years of age were not interested in changing their current dwelling. Moreover, those who indicated that they were not interested in changing their place of residence assessed their housing conditions as good or very good. In relation to whether housing conditions are adapted to the housing needs of older people, respondents often indicated that these housing conditions are not appropriate. They would be more likely to decide to change their place of residence.

The influence on the willingness to stay in their current dwelling may result from the current housing conditions of the respondents. As many as half of the respondents indicated that their housing conditions were rather good, and almost $39 \%$ of those surveyed indicated that they were very good. Nearly $6 \%$ of the respondents were unable to assess their housing conditions, and only slightly more than $5 \%$ of the respondents said that their conditions were rather bad. No one indicated that their 
conditions were definitely bad. The responses of seniors and people of pre-senior age were similar in this respect.

The opinion of the respondents was slightly different when they were asked to assess the housing conditions in the context of the assessment of their residence by an older person. Figure 4 shows the answers of the respondents to the question: In your opinion, is the current dwelling adapted to the housing conditions of older people?

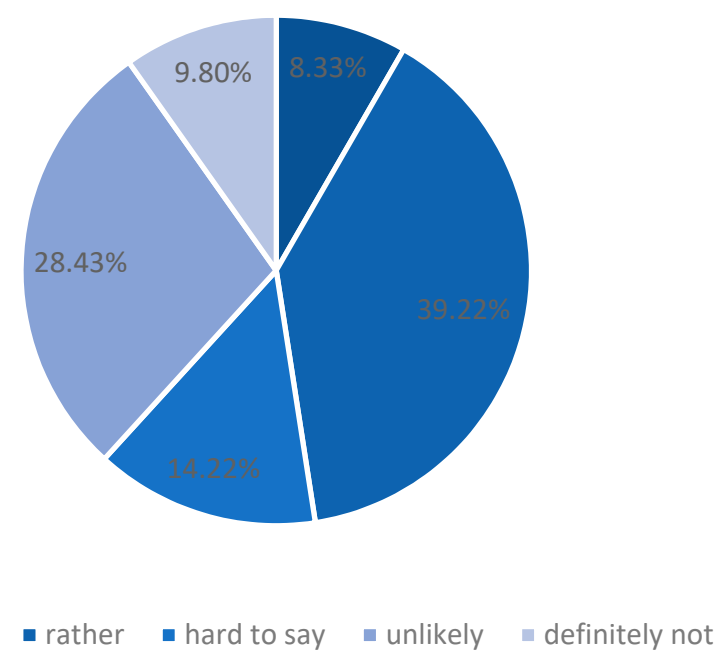

Figure 4. Answers to the question: In your opinion, is the current dwelling suitable for older people? Source: Own study based on the research conducted.

Most people indicated that their dwelling was rather adapted to be inhabited by an older person; slightly more than $39 \%$ of those surveyed. However, a considerable number of respondents expressed a negative opinion in this respect, claiming that the dwelling is rather not adapted to be inhabited by an older person or definitely not. About $14 \%$ of the respondents did not express an opinion in this respect, choosing the answer "hard to say".

People over 70 years of age were more likely than younger people to indicate that their housing conditions are rather adapted to the elderly. Seniors aged 60-69 most often responded that their housing conditions are not adapted to their needs i.e., the needs of older people.

The decision to change dwelling may be influenced by various other factors. Eight of these were identified for the purposes of the research. The factors are presented below with a description.

Terms of apartment purchase: Understood as the price of purchase/rental/swap of the apartment, costs accompanying the purchase/rental/swap of the apartment, as well as the method of payment required for the transaction.

Communication: Location of the building in a place where communication between the place of residence and the places needed by the buyer is satisfactory and possible thanks to the presence of efficient public transport (including bus, train).

Type of building: Defined by the type of development (single-family house, multi-family building), design and size of the building, technology of execution.

Building equipment: Otherwise convenient development of the building, e.g., monitoring, security, elevator, separate part of the property for parking spaces in front of the building or garage hall, and friendly development of common parts of buildings in case of multi-family buildings, e.g., wide, well-lit staircase; benches; playgrounds; greenery arrangements.

Characteristics of the apartment: Described by such features as: area of the apartment, number of rooms, layout of the apartment, location in the building (the floor on which the apartment was located), and directions faced by windows in the apartment, as well as the provision of additional areas such as a balcony, terrace, tenant's cell, or basement. 
Neighborhood: Limited to the area of the estate, sometimes including the street, and assessed in relation to green areas, recreation places, safety of the district, and traffic intensity. Views from windows were also important, in addition to the type of neighborhood in terms of both the area's function and the human factor.

The infrastructure of the housing estate: Understood as guaranteeing appropriate technical infrastructure (i.e., paved access roads and sidewalks) and service and commercial infrastructure (the existence of an appropriate number of grocery and industrial shops, pharmacies, clinics, churches, cinemas, etc.).

Social factors: Interpreted through sentiment towards the current neighborhood and neighbors, and a barrier to the acceptance of new neighbors, and in relation to closeness to family members when a move would potentially increase the distance between the family and the new place of residence.

The respondents were asked to assess the importance of particular factors from the point of view of their influence on the choice of a new dwelling. The respondents answered on a scale-very important, important, I do not have an opinion, rather irrelevant, definitely irrelevant-thus allowing a ranking of individual factors to be created. A weighted average was used for this purpose, defining the weights as numerical values from 5 to 1 , according to the adopted response scale. The highest weight was given to the answer in which the respondent indicated that the factor was very important to them. In turn, the lowest weighting was assigned to the response in which the respondent expressed the lowest approval for the examined factor.

Figure 5 shows a ranking of factors from the most important to the least important in the case of a change of residence.

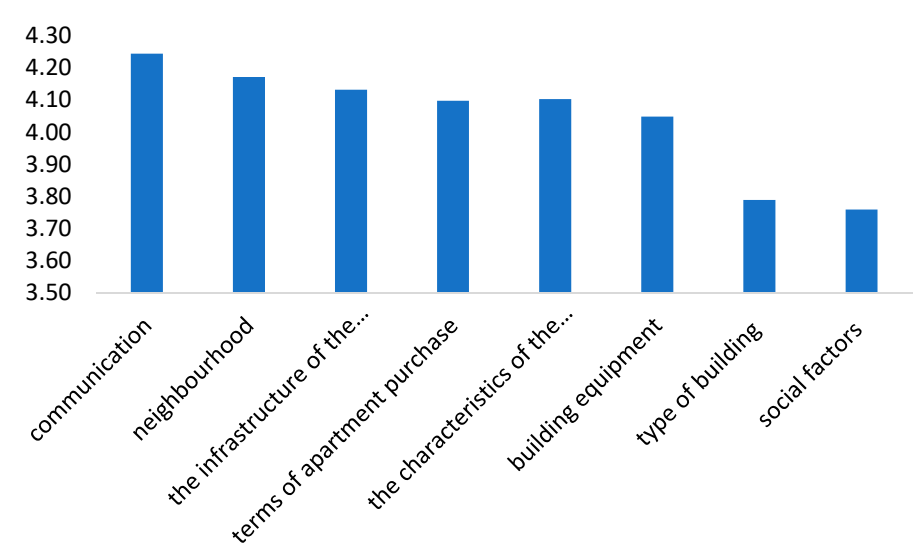

Figure 5. Relevance of factors for a new dwelling. Source: Own study based on the research conducted.

Among the factors distinguished, the most important for the respondents was good public transport (e.g., bus, train) between the dwelling and places important for the respondent (the importance of the factor was rated at 4.25). Another important factor for the respondents was the location of the residential building where their dwelling would be located. Almost the same importance was attached to the housing estate's infrastructure (factor importance at the level of 4.13). For the respondents, the least important factor was the search for a new dwelling near the place of residence of family and friends (the importance of the factor was rated at 3.76). It should be emphasized that for the respondents the most important factor for the selection of a new dwelling was not the conditions of purchase of a new place of residence, including the cost of purchasing a new dwelling. The oldest seniors-over 70 years of age-most often indicated that their location and location close to family and friends would be important when moving house. The aspect of transport, on the other hand, was the most important for seniors aged 60-69. In Table 1, the summary of respondents' answers concerning their housing preferences in terms of type of development, number of rooms, and location of a new flat is presented. 
Table 1. Housing preferences in relation to type of development, number of rooms, and location of new apartment (in \%).

\begin{tabular}{|c|c|c|c|c|}
\hline & \multirow{2}{*}{ Answers } & \multicolumn{3}{|c|}{ Age of Citizens } \\
\hline & & $50-59$ & $60-69$ & 70 and More \\
\hline \multirow{6}{*}{ type of building } & low apartment block (up to 4 floors) & 13.73 & 21.57 & 12.75 \\
\hline & high apartment block (above 4 floors) & 0 & 4.41 & 1.47 \\
\hline & tenement house & 1.47 & 2.94 & 0.98 \\
\hline & single-family home & 11.27 & 5.39 & 7.35 \\
\hline & terraced & 5.39 & 3.43 & 2.45 \\
\hline & other & 3.43 & 0 & 1.96 \\
\hline \multirow{4}{*}{ number of rooms } & 1 room & 0.49 & 0.49 & 0 \\
\hline & 2 rooms & 7.35 & 14.22 & 11.76 \\
\hline & 3 rooms & 20.59 & 18.14 & 12.25 \\
\hline & 4 and more & 6.86 & 4.9 & 2.94 \\
\hline \multirow{3}{*}{ location } & city center & 6.37 & 14.22 & 8.82 \\
\hline & out of the city center & 23.53 & 22.06 & 17.16 \\
\hline & village & 5.39 & 1.47 & 0.98 \\
\hline
\end{tabular}

Source: Own study based on the research conducted.

Almost half of the respondents indicated that if a new dwelling was chosen, they would want it to be located in a low block of flats, with up to 4 floors. On the other hand, almost one-quarter of the respondents would decide to live in a single-family house. Among those deciding to live in a single-family house, the most frequent were people of pre-senior age, whose monthly disposable income exceeded PLN 2500. From answers to the question of "other, what kind?" there were indications that people would live in a block of flats regardless of the number of floors, but an elevator would be an important of equipment for the building.

Although a small percentage of respondents would be interested in living in a small apartment (i.e., one room), respondents would most often choose three- or two-room apartments. Two-bedroom flats were most often chosen by people who lived in single or two-person households. Similar preferences were observed in studies conducted by Tanaś et al. [55]. Seniors most often bought three-room flats.

Most people indicated that they would still like to live in a big city, but outside the city center. People aged 60-69 usually wanted to live in the city center. People in the pre-senior age group, rather than seniors, were more likely to live outside the city center and in the countryside.

Later questions in the survey examined whether respondents were familiar with the term "seniors' housing" and what solutions regarding this type of housing would be important for the respondents.

Figure 6 presents a summary of the answers to the question: Have you ever heard of senior citizens' housing before?

Almost $30 \%$ of the respondents indicated that they had rather heard of senior housing and almost one-fifth of respondents indicated that they had heard of senior housing many times. However, a similar share of respondents indicated that they had rather not heard of senior housing, certainly had not heard of it, or did not know whether they had heard of it. It can therefore be assumed that apartments for seniors are not a popular and generally available form in Poland. Most often people aged 60-69 had heard about the construction of housing for seniors, with people over 70 the least likely to have heard about it.

Respondents were skeptical about whether they would live in senior housing, which may be due to their little knowledge of the forms of housing for seniors. Most people indicated that they did not know whether they would move to senior housing: almost $30 \%$ of the respondents. The remaining answers were distributed proportionally to the lack of interest in this type of housing. The most willing to move to senior housing were people aged $60-69$, and the least willing were those over 70 . It is 
possible that people with an average disposable income of PLN 1500-2500 per month/person in the household would also be interested in moving to this type of housing.

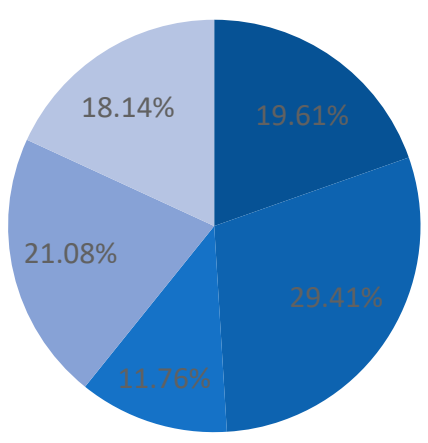

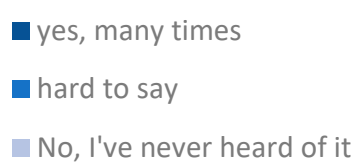

-yes, many times

- hard to say

No, I've never heard of it

Rather, yes, I've heard of it.

- I don't think so, although I'm not sure

Figure 6. Answers to the question: Have you ever heard of senior citizens' housing before? Source: Own study based on the research conducted.

In the next question, the respondents were asked to indicate what form of housing development would be appropriate for senior citizens. Table 2 presents a list of preferred forms of housing in the opinion of respondents.

Table 2. Preferred form of residence according to the respondents.

\begin{tabular}{|c|c|c|}
\hline Feature & The Response Option & Percentage of Indications \\
\hline Preferred form of residence & $\begin{array}{c}\text { existing apartment converted for the needs of an elderly person } \\
\text { (architectural facilities) } \\
\text { a new apartment from the developer in a multi-family building, } \\
\text { meeting the needs of an elderly person (architectural facilitation) } \\
\text { living in a building where there are only apartments for the elderly } \\
\text { without additional services } \\
\text { an apartment in a building which contains only apartments for the } \\
\text { elderly with additional services } \\
\text { a terraced house or a single-family house adapted for living by an } \\
\text { elderly person } \\
\text { a higher standard apartment (apartment) adapted to be inhabited by an } \\
\text { elderly person } \\
\text { shared rooms in a nursing home } \\
\text { independent nursing home } \\
\text { Other? }\end{array}$ & $\begin{array}{l}25.00 \% \\
26.47 \% \\
0.00 \% \\
19.12 \% \\
13.73 \% \\
6.86 \% \\
0.00 \% \\
3.92 \% \\
4.90 \%\end{array}$ \\
\hline
\end{tabular}

Source: Own study based on the research conducted.

Respondents most often indicated that they would move to a new apartment from a developer in a multi-family building that would meet the needs of an elderly person (i.e., with architectural facilities) or they would like to stay in their existing apartment and adapt it to the needs of an elderly person in terms of architectural facilities. Slightly more than $19 \%$ of the respondents indicated that they would live in a building with only apartments for the elderly, but only if additional services for the residents were guaranteed, e.g., in the form of medical care. The respondents were not interested in living in a social welfare home; a small percentage of respondents indicated interest in living in a nursing home, but only if they had an independent room. In the answer "other, what?" the respondents indicated that they would be interested in different forms, depending on their health condition, or expressed hesitation.

The oldest respondents-i.e., over 70 years old-would most often want to stay in their current dwelling. New flats from a developer, in a building with architectural facilities or an 
apartment in a building with apartments for seniors with additional services, would be chosen by people aged $60-69$. The youngest respondents, aged 50-59, would most often want to live in a single-family house or a terraced house adapted to be inhabited by an elderly person compared to other age groups.

In the next question, the respondents were asked to indicate the type of services that could complement the offer of housing for seniors. The following types of services were proposed to the respondents:

Catering, which would be related to the introduction of a canteen, restaurant, or catering service into the apartment.

Medical-care services: Medical services consist of providing seniors living in the area of a medical care building with a doctor and a nurse; care services are connected with helping people who are specially prepared for this purpose in their daily activities, e.g., cleaning the apartment, hanging curtains, throwing away rubbish.

Rehabilitation: The possibility to use rehabilitation services within the building only for residents.

Culture: Organizing a cultural offering on the premises of the building, which guarantees the possibility of spending free time for seniors, e.g., through the operation of a senior citizens' club organizing various forms of entertainment, such as trips to the cinema or theatre.

Transport: Possibility of ordering transport of persons (e.g., taxis) with the help of a housekeeper.

Hairdressing and cosmetology: Introduction of hairdressing and cosmetology services on the premises of the property with the possibility of ordering services to the apartment.

Security: Employment of a security company and the possibility of establishing monitoring, and fencing of the building and common parts of the property.

Assistance in making purchases: The possibility of ordering purchases by the housekeeper and the introduction of a multi-branch shop, pharmacy, etc., on the property.

Respondents were asked to assess the importance of selected services in senior citizens' housing. To this end, the respondents assessed each factor on a scale: very important, important, I don't have an opinion, rather unimportant, definitely unimportant. The selection of the most needed services was determined on the basis of the weighted average (similarly to the ranking of factors influencing the purchase of a new dwelling). The highest weighting was given to the answer in which the respondent indicated that the service was very important. In turn, the lowest weighting was assigned to the answer in which the respondent indicated that the service was definitely irrelevant.

Figure 7 shows the types of services from the most to the least needed in senior citizens' housing.

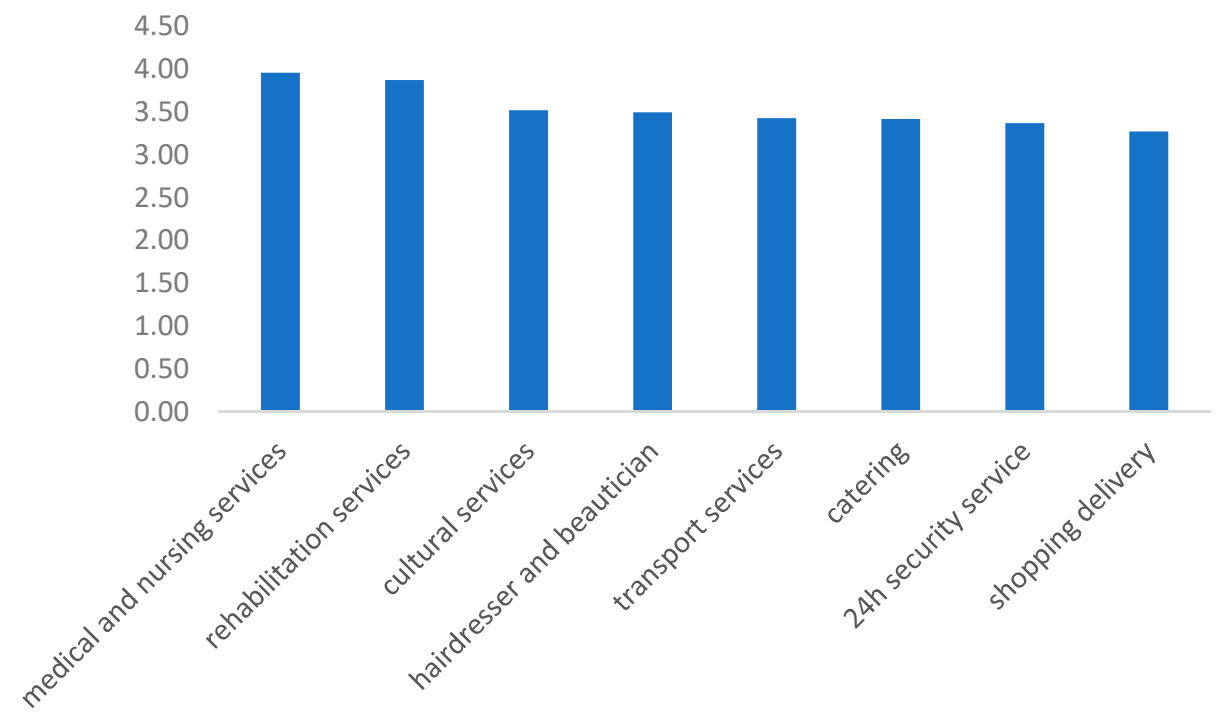

Figure 7. Overview of the type of services from most to least needed in housing to which the respondents would move. Source: Own study based on the research conducted. 
The respondents most often indicated that in their new place of residence they would primarily value access to medical and nursing services (the importance for medical and nursing services was assessed at 3.96). Rehabilitation services were also important for the respondents (the importance of rehabilitation services was assessed at the level of 3.87). The respondents indicated that when choosing a new flat, they would rarely pay attention to whether the facility was monitored or whether it was possible for shopping to be delivered. Seniors over 70 years old most often thought about services of a medical nature.

In the last question, the respondents were asked to indicate how they would finance a possible change of dwelling, as shown in Figure 8.
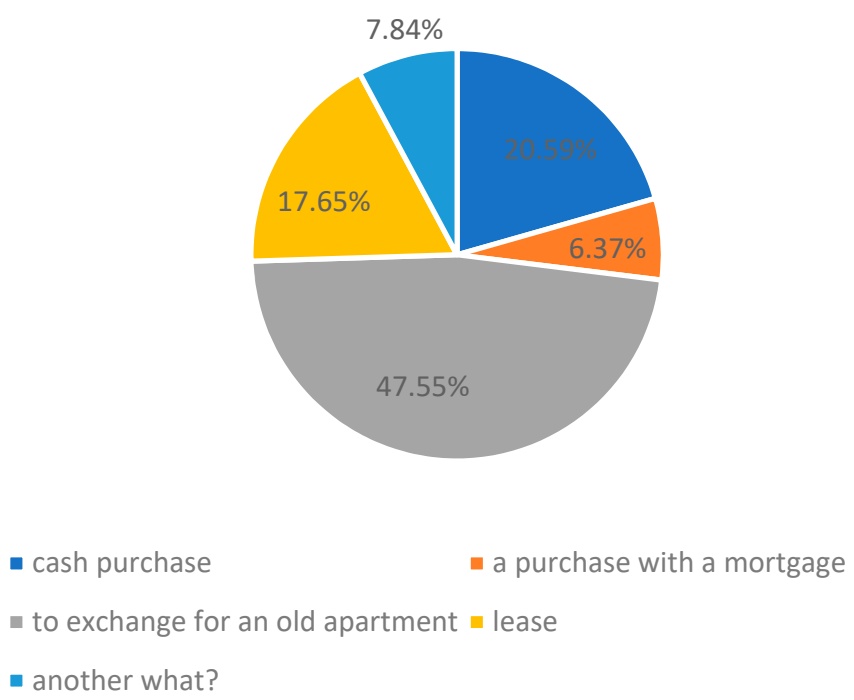

Figure 8. Answers to the question: How would you be willing to finance the purchase of a new dwelling? Source: Own study based on the research conducted.

Respondents indicated that if they decided to change their apartment, they would be most willing to replace the old one with a new one: nearly $48 \%$ of the respondents. The respondents would also be interested in purchasing a flat for cash or a long-term rental. It should be noted that in the surveyed group, a high percentage of respondents indicated that they would have the capital to buy a new flat for cash; these were mainly senior citizens (over 60 years of age). The answer to the question "other, what?" was that the respondent would live with his or her family or partner, or it would depend on his or her future financial situation.

\section{Attitude of Inhabitants Towards Senior Citizens' Housing}

This section discusses the attitude of inhabitants of large cities (over 100,000 inhabitants) over 50 years of age in the Wielkopolskie Voivodeship towards senior citizens' housing. The statistical research is an extension of previously conducted surveys.

The attitude towards senior citizens' housing was measured on the basis of the answers given to questions specially selected for this purpose. These questions concerned knowledge in the field of senior housing, the adaptation of the current premises to be inhabited by the elderly, the need to develop senior housing, and interest in moving to such premises. The answers were quantified using the Likert scale. It was assumed that the attitude towards senior housing could be positive, negative, or undecided. The attitude of the respondents was determined using a synthetic attitude indicator.

For the purpose of the conducted research - to identify the respondents' attitudes towards senior housing - a set of four questions describing the attitudes of the respondents was selected. These questions were included in the questionnaire, as follows:

(1) Have you ever heard of senior citizens' apartments before? 
(2) In your opinion, is the current dwelling suitable for the elderly?

(3) In your opinion, is there a need to build apartments for seniors?

(4) Would you be interested in moving to a senior citizens' apartment in the future?

The answers were presented using a five-step Likert scale. The scale helped to give direction and strength to the answers given, and to order the respondents' answers from the least to the most favorable.

The first question was to examine the respondent's knowledge in the field of senior housing. The second and third questions referred to the emotions and motivations of the respondent. The respondent expressed his or her opinion whether his or her premises were adapted to be inhabited by an older person and whether he or she believes that there is a need to build apartments for seniors. The last question, in which the respondent indicated to what extent $\mathrm{s} /$ he would be interested in moving to a flat for seniors in the future, concerned the behavioral sphere.

Table 3 presents the questions and the scale of answers used to assess the attitudes of respondents. These questions were part of the questionnaire survey. The response options were transferred from the questionnaire and arranged according to the Likert scale. The variants of answers to the questionnaire were given integer values on a five-stage scale ranging from -2 to 2 . A value of +2 meant a positive attitude of the respondent toward senior citizens' housing, and a value of -2 indicated a negative attitude.

Table 3. Question set and response assessment scales used to survey respondents' attitudes.

\begin{tabular}{|c|c|c|c|c|c|}
\hline \multirow{2}{*}{$\begin{array}{c}\text { QUESTION 1: } \\
\text { The response option }\end{array}$} & \multicolumn{5}{|c|}{ Have You Ever Heard of Senior Citizens' Apartments Before? } \\
\hline & yes, many times & $\begin{array}{l}\text { Rather, yes, I've } \\
\text { heard of it. }\end{array}$ & hard to say & $\begin{array}{l}\text { I don't think so, } \\
\text { although I'm not sure }\end{array}$ & $\begin{array}{c}\text { No, I've never heard } \\
\text { of it }\end{array}$ \\
\hline Weight & +2 & +1 & 0 & -1 & -2 \\
\hline QUESTION 2: & \multicolumn{5}{|c|}{ In your opinion, is the current dwelling suitable for the elderly? } \\
\hline The response option & definitely not & unlikely & hard to say & rather & certainly \\
\hline Weight & +2 & +1 & 0 & -1 & -2 \\
\hline QUESTION 3: & \multicolumn{5}{|c|}{ In your opinion, is there a need to build apartments for seniors? } \\
\hline The response option & certainly & rather & hard to say & unlikely & definitely not \\
\hline Weight & +2 & +1 & 0 & -1 & -2 \\
\hline QUESTION 4: & \multicolumn{5}{|c|}{ Would you be interested in moving to a senior citizens' apartment in the future? } \\
\hline The response option & certainly & rather & hard to say & unlikely & definitely not \\
\hline Weight & +2 & +1 & 0 & -1 & -2 \\
\hline
\end{tabular}

In the case of the first question, it was assumed that having knowledge in the field of senior citizens' housing can shape a positive attitude. The answer "yes, many times" represented the most positive attitude of the respondent to the analyzed phenomenon, thus in the Likert scale the answer was valued as +2 . On the other hand, a lack of knowledge about senior housing may intensify the reluctance towards this housing, therefore, the answers "I don't think so, although I am not sure" and "no, I have never heard of it" received the lowest values in the Likert scale.

In the second question, it was assumed that when the current dwelling is adapted to the housing of the elderly, the respondents would not be interested in moving into senior citizens' housing, thus their attitude would be negative. On the other hand, people who do not have suitable accommodation for older people are likely to be more interested in senior citizens' housing and their attitude will be positive.

In the third question, the highest weighting was given to the answers in which the respondents claimed that there was a need to build apartments for seniors. In turn, the lowest values were assigned to the answers in which the respondent claimed that there was no need to develop housing for seniors. It can be assumed that with a negative attitude to the development of these types of facilities, the respondent will not prefer to live in this type of housing.

In question four, those who indicated that they would be interested in moving to senior housing have a positive attitude towards senior housing. 
There are three types of attitudes, namely, positive, undecided, and negative attitudes. Figure 9 shows the dependence of the type of attitude on the value of the synthetic index.

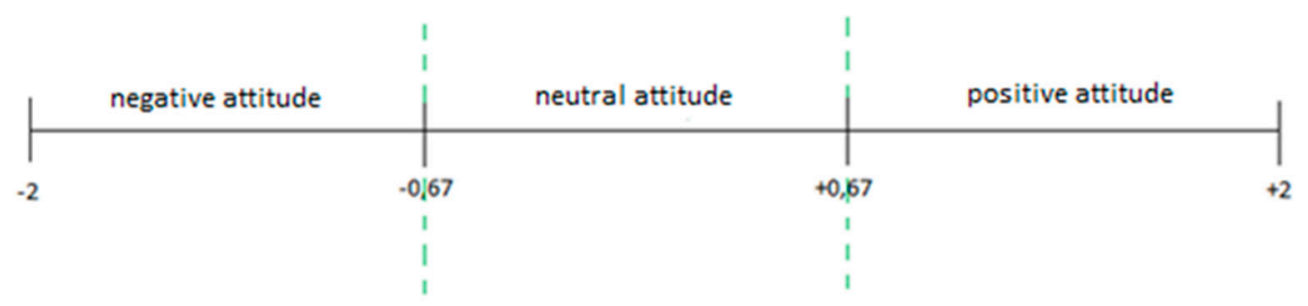

Figure 9. The attitude type depends on the value of the synthetic index. Source: Own study.

The quantitative measure describing the attitude of the respondent was between -2 and +2 (Figure 9). This range was divided into three equal parts:

(1) -2 to -0.67 : negative attitude;

(2) -0.67 to +0.67 : undecided attitude;

(3) +0.67 to +2 : positive attitude.

The quantitative measure of the respondents' attitude was the average of the weights of their answers.

The attitude of respondents towards senior citizens' housing was determined by means of a synthetic index, according to the formula

$$
W_{s}=\frac{2 \sum_{i=1}^{r} a+1 \sum_{i=1}^{r} b+(-1) \sum_{i=1}^{r} d+(-2) \sum_{i=1}^{r} e}{\mathrm{rn}}
$$

where

a-The number of extremely favorable responses;

$\mathrm{b}$-Number of moderately favorable responses;

$\mathrm{d}$-Number of moderately negative responses;

e-Number of extremely negative responses;

i-Question number;

$\mathrm{r}-$ Number of questions used for attitude testing;

$\mathrm{n}-$ Number of respondents.

Table 4 presents an assessment of respondents' attitudes towards senior housing among residents of cities with more than 100,000 inhabitants in Wielkopolskie Voivodeship.

The evaluation of the attitudes of respondents from cities with populations over 100,000 in Wielkopolskie Voivodeship carried out with the use of a synthetic indicator showed that the surveyed group is characterized by a neutral attitude towards senior citizens' housing. The attitude towards senior citizens' housing construction is undecided. The synthetic index for this group was 0.4167 .

This attitude stems from the expression of uncertainty about the knowledge of senior citizens' housing and the indication that the current housing is not adapted to the residence of the elderly. However, the respondents argued that the development of senior housing is needed. The respondents' answers to a possible change of place of residence to residential construction are not clear. The total attitude of the respondents is therefore characterized by indecision. 
Table 4. Evaluation of respondents' attitudes from cities with more than 100,000 inhabitants.

\begin{tabular}{|c|c|c|c|c|c|c|c|c|c|c|c|c|}
\hline \multirow{2}{*}{$\begin{array}{c}\text { Scale of Assessment } \\
\text { Content of the Question }\end{array}$} & \multicolumn{2}{|c|}{+2} & \multicolumn{2}{|c|}{+1} & \multicolumn{2}{|c|}{0} & \multicolumn{2}{|c|}{-1} & \multicolumn{2}{|c|}{-2} & \multicolumn{2}{|c|}{ Total } \\
\hline & $\mathbf{a}$ & $\%$ & $\mathbf{b}$ & $\%$ & c & $\%$ & d & $\%$ & e & $\%$ & $\mathbf{n}$ & $\%$ \\
\hline \multirow{2}{*}{$\begin{array}{l}\text { 1. Have You Ever Heard of Senior Citizens' } \\
\text { Apartments Before? }\end{array}$} & \multicolumn{2}{|c|}{ yes, many times } & \multicolumn{2}{|c|}{$\begin{array}{l}\text { Rather, yes, I've heard } \\
\text { of it. }\end{array}$} & \multicolumn{2}{|c|}{ hard to say } & \multicolumn{2}{|c|}{$\begin{array}{l}\text { I don't think so, } \\
\text { although I'm not sure }\end{array}$} & \multicolumn{2}{|c|}{$\begin{array}{l}\text { No, I've never heard of } \\
\text { it }\end{array}$} & & \\
\hline & 40 & 19.61 & 60 & 29.41 & 24 & 11.76 & 43 & 21.08 & 37 & 18.14 & 204 & 100 \\
\hline \multirow{2}{*}{$\begin{array}{l}\text { 2. In Your Opinion, Is the Current Dwelling } \\
\text { Suitable for the Elderly? }\end{array}$} & \multicolumn{2}{|c|}{ definitely not } & \multicolumn{2}{|c|}{ unlikely } & \multicolumn{2}{|c|}{ hard to say } & \multicolumn{2}{|c|}{ rather } & \multicolumn{2}{|c|}{ certainly } & & \\
\hline & 17 & 8.33 & 80 & 39.22 & 29 & 14.22 & 58 & 28.43 & 20 & 9.80 & 204 & 100 \\
\hline \multirow{2}{*}{$\begin{array}{l}\text { 3. Do You Think There Is a Need to Build } \\
\text { Apartments for Seniors? }\end{array}$} & \multicolumn{2}{|c|}{ certainly } & \multicolumn{2}{|c|}{ rather } & \multicolumn{2}{|c|}{ hard to say } & \multicolumn{2}{|c|}{ unlikely } & \multicolumn{2}{|c|}{ definitely not } & & \\
\hline & 129 & 63.24 & 45 & 22.06 & 19 & 9.31 & 10 & 4.90 & 1 & 0.49 & 204 & 100 \\
\hline \multirow{2}{*}{$\begin{array}{l}\text { 4. Would You Be Interested in Moving to a } \\
\text { Senior Citizens' Apartment in the Future? }\end{array}$} & \multicolumn{2}{|c|}{ certainly } & \multicolumn{2}{|c|}{ rather } & \multicolumn{2}{|c|}{ hard to say } & \multicolumn{2}{|c|}{ unlikely } & \multicolumn{2}{|c|}{ definitely not } & & \\
\hline & 35 & 17.16 & 37 & 18.14 & 59 & 28.92 & 49 & 24.02 & 24 & 11.76 & 204 & 100 \\
\hline Total & \multicolumn{2}{|c|}{$\sum \mathrm{a}=221$} & \multicolumn{2}{|c|}{$\sum \mathrm{b}=222$} & \multicolumn{2}{|c|}{$\sum \mathrm{c}=131$} & \multicolumn{2}{|c|}{$\sum \mathrm{d}=160$} & \multicolumn{2}{|c|}{$\sum \mathrm{e}=82$} & \multicolumn{2}{|c|}{$\mathrm{r} \times \mathrm{n}=816$} \\
\hline Synthetic Indicator (Wspg) & & & & & & Wsp & 0.4167 & & & & & \\
\hline
\end{tabular}

Source: Own study based on the research conducted. 


\section{Conclusions}

Senior housing is part of the silver economy concept. It is a type of housing in which the needs of older people play a special role. This type of housing guarantees seniors an appropriate standard of living space and building in terms of architectural facilities and services, particularly regarding care, medical services, and rehabilitation. However, the segment of senior citizens' housing is not sufficiently developed in Poland, and there is also a lack of direction for this type of housing.

In Poland, the study of housing preferences is a common issue in the literature. However, there is a lack of studies that describe the housing preferences of older people. The housing preferences of seniors have not been sufficiently researched, thus it is difficult to determine a clear direction of development of this population segment in Polish conditions. The existing research results indicate that seniors in Poland do not want to change their place of residence. Only a small percentage of respondents indicate that they plan to change their place of residence due to poor housing conditions in terms of the elderly or for health reasons. Similar relationships are presented in this article.

The respondents, who were seniors and senior citizens from large cities in the Wielkopolskie Voivodeship, did not express willingness to change their dwellings. The results of the research are consistent with national trends, which indicate that the elderly prefer to live independently for as long as possible, according to so-called "aging in place" $[14,18]$. Andrews (2010) pointed out that in the USA assisted living services are provided for more than one million elderly people in 36,000 institutions dealing with this type of service provision in the place of residence. It should also be noted that, with age, the propensity to migrate decreases [14]. This trend was also visible in the results of the current research.

However, this does not mean that the willingness to stay in the current dwelling was related to the recognition of the dwelling as suitable for the elderly. Seniors, most often aged 60-69, responded that as much as their housing conditions are good, they are not always suitable for the elderly, who often need more facilities due to reduced mobility. It should be pointed out here, for example, that the area of the apartment is too large, followed by high maintenance costs. Too big a flat is also connected with the lack of possibility to clean it due to health condition. Older people often live in an old housing stock, which is often associated with a low standard of use, e.g., the lack of a lift in a residential building and its location is above the first floor. Similar conclusions are included in the study conducted by Szukalski [10].

Research has shown that the preferences of seniors and pre-senior citizens differ. Housing preferences also depend on age-the responses of 60-69-year-olds often differed from those over 70 years of age. It should be noted that the housing preferences of people in pre-seniority may also change as they enter retirement age.

Differentiation of housing preferences was visible primarily when choosing the type of development and size of the dwelling. Seniors preferred smaller units in multi-family housing constructions. Pre-senior citizens, on the other hand, were more likely to think about living in a single-family house. The location of a new dwelling was also important. Seniors, more often than people aged 50-59, chose a location in the city center. Pre-senior citizens, on the other hand, indicated they would more often decide to live in a rural area or outside the city center.

Those most interested in a possible change of place of residence, including living in buildings intended for the elderly, were people aged 60-69 years. This age group would most often choose residential units in new development projects, where architectural facilities are guaranteed for people with reduced mobility and in housing designed exclusively for the elderly, where additional services for the elderly are offered. Seniors over 70 years of age most often indicated that they would not want to change their place of residence but would adapt their current apartment to their needs, however, if they had to move, they would pay attention to the location of the apartment and their position in relation to family and friends. 
The most interested group in senior citizens' housing were people aged 60-69. It can be assumed that these are people who start to notice the first signs of old age. Due to their current mobility, health, and material situation, they are able to make decisions to improve their housing situation.

On the basis of the research carried out, it should be concluded that housing construction for seniors should develop primarily in terms of adjusting the current housing stock of seniors, e.g., through a renovation subsidy scheme. However, it should be noted that there will be a group of seniors who will also attempt to change their place of residence. Given the preferences examined, new apartments from developers, in buildings with architectural facilities, or apartments in buildings in which there are only apartments for seniors with additional services, may meet with the greatest interest. These apartments should be built within a large city, and outside the center of the city.

The attitude of seniors towards senior citizens' housing is undecided, which may indicate that many people may change their housing preferences in the future and decide to move. This attitude is due to a lack of seniors' knowledge of the housing solutions available to them. The respondents also believed that housing for older people should be developed, but many people did not know whether they would like to take advantage of senior housing. The hypothesis, in this respect, has not been confirmed.

The study has some limitations. The survey was conducted only in cities with more than 100,000 inhabitants in the Wielkopolskie Voivodeship. The research could be extended to other large cities in Poland. Moreover, the difficulties in conducting the survey resulted from obtaining questionnaires from elderly people, especially those over 70 years of age. The research was cost- and time-consuming. Conducting the research required the preparation of a questionnaire that would be readable for the elderly, including a larger text font. Often the respondents asked for additional explanation of the content of the questions.

Research on the housing preferences of the elderly should be extended to include an additional area of researchers, and divided into cities with more than 100,000 inhabitants, medium-sized towns, small towns, and villages. Moreover, the research should sufficiently emphasize the characteristics of the surveyed group, such as age, education, number of people in the household, and disposable income per person in the household/month. These surveys should be conducted periodically, as housing preferences may change.

Author Contributions: A.J. designed research and wrote the paper, R.T. provided extensive advice throughout the study regarding the abstract, introduction, literature review, research methodology and data, and results of the manuscript. The discussion was a team task. All authors have read and agreed to the published version of the manuscript.

Funding: This research received no external funding.

Conflicts of Interest: The authors declare no conflict of interest.

\section{References}

1. Pierzchalska, A.; Klag, P. Społeczne role osób starszych. In Równość w Unii Europejskiej. Teoria i Praktyka; Bokajło, W., Pacześniak, A., Eds.; Wrocławskie Wydawnictwo Naukowe Atla 2: Wrocław, Poland, 2008; pp. 437-448.

2. Waligórska, M.; Kostrzewa, Z.; Potyra, M.; Rutkowska, L. Prognoza Ludności Na Lata 2014-2050; GUS: Warsaw, Poland, 2014; ISBN 9788370274351.

3. Klimanek, T.; Filas-Przybył, S. The statistical picture of population aging in towns of Wielkopolskie Province: TERYT and DE-GURBA perspectives. J. Econ. Manag. 2020, 39, 41-61. [CrossRef]

4. Kim, J.I.; Kim, G. Socio-ecological perspective of older age life expectancy: Income, gender inequality, and financial crisis in Europe. Global. Health 2017, 13, 1-8. [CrossRef] [PubMed]

5. Murphy, M. Demographic Determinants of Population Aging in Europe since 1850. Popul. Dev. Rev. 2017, 43, 257-283. [CrossRef]

6. Liu, Y. Aging and economic growth: Is there a role for a two-child policy in China? Econ. Res. Istraz. 2020, 33, 438-455. [CrossRef] 
7. Tanas, J.; Trojanek, R. Demographic structural changes in Poznań downtown: In the light of the processes taking place in the contemporary cities in the years 2008 and 2013. J. Int. Stud. 2015, 8. [CrossRef]

8. Trojanek, M.; Tanaś, J.; Trojanek, R. Changes in the Demographic Structure of the Central City in the Light of the Suburbanization Process (The Study of Poznań). In Smart City 360 ; Springer: Cham, Switzerland, 2016.

9. Błędowski, P.; Szatur-Jaworska, B.; Szweda-Lewandowska, Z.; Kubicki, P. Raport na Temat Sytuacji osób Starszych w Polsce; Instytut Pracy i Spraw Socjalnych: Warszawa, Poland, 2012.

10. Szukalski, P. Sytuacja mieszkaniowa seniorów w przyszłości. Demogr. i Gerontol. Społeczna-Biuletyn Inf. 2017, nr11, 1-6.

11. Zasępa, B. Wpływ procesu starzenia się ludności na system emerytalny. In Polska a Europa. Procesy Demograficzne u Progu XXI Wieku; Frąckiewicz, L., Ed.; Wydawnictwo: Śląsk, Poland, 2002; pp. 27-43.

12. Golinowska, S. Polityka rodzinna a przemiany rodziny, gospodarki i państwa. Głos w debacie o polityce rodzinnej w Polsce. Polityka Społeczna 2007, 8, 8-13.

13. Błędowski, P.; Szweda-Lewandowska, Z. Polityka Wobec Starości i Starzenia Się w Polsce w Latach 2015-2035. Aspekty Teoretyczne i Praktyczne; Instytut Pracy i Polityki Społecznej: Warsaw, Poland, 2016.

14. Kirejczyk, K.; Brzeski, W.; Kozłowski, E. Budownictwo Senioralne w Polsce. Perspektywy Rozwoju; REAS: Warsaw, Poland, 2015.

15. Wyszkowska, D.; Gabińska, M.; Romańska, S. The Situation of Older People in Poland in 2018; GUS: Warsaw, Poland, 2020.

16. Wądołowska, K. Polacy Wobec Ludzi Starszych i Własnej Starości; CBOS: Warsaw, Poland, 2009.

17. Przybyła, K.; Hełdak, M.; Kurtyka-Marcak, I. Demand for a housing offer addressed to senior citizens in Poland. Int. J. Environ. Res. Public Health 2019, 16. [CrossRef]

18. Iwański, R.; Rataj, Z.; Cieśla, A. Housing Needs of Older People in Poland as Exemplified by the Warsaw, Poznań and Szczeciń Urban Areas. Real Estate Manag. Valuat. 2019, 27, 126-137. [CrossRef]

19. Zrałek, M. Zaspokojenie potrzeb mieszkaniowych osób starszych. Dylematy i kierunki zmian. In O Sytuacji Ludzi Starszych; Hrynkiewicz, J., Ed.; Rządowa Rada Ludnościowa; Zakład Wydawnictw Statystycznych: Warszawa, Poland, 2012.

20. Kłobukowska, J. Polityka mieszkaniowa wobec starzenia się społeczeństw-Podstawowe wyzwania. Świat Nieruchom. 2014, 35-40. [CrossRef]

21. Niezabitowski, M. Znaczenie miejsca zamieszkania w życiu ludzi starszych. Aspekty teoretyczne i empiryczne. Probl. Polityki Społecznej. Stud. i Dyskusje 2014, 24, 81-101.

22. Jancz, A. Potrzeby mieszkaniowe osób starszych i ich opinie na temat budownictwa senioralnego. Stud. i Pr. WNEiZ 2016, 45/1, 305-316. [CrossRef]

23. Burzynska, A.Z.; Malinin, L.H. Enriched Environments for Healthy Aging: Qualities of Seniors Housing Designs Promoting Brain and Cognitive Health. Seniors Hous. Care J. 2017, 25, 15-37.

24. Dudek-Mańkowska, S. Mieszkanie dla seniora-Formy budownictwa senioralnego oraz stan ich rozwoju w Polsce. Konwersatorium Wiedzy o Mieście 2017, 30. [CrossRef]

25. Magdziak, M. Mieszkalnictwo Dla Osób Starszych W Stanach Zjednoczonych Ameryki Pół Nocnej. Archit. Artibus 2009, 1, 38-45.

26. Pytel, S. Osiedla mieszkaniowe dla seniorów w przestrzeni miast. Pr. Kom. Kraj. Kult. 2014, 25, $155-165$.

27. Labus, A. Domy międzypokoleniowe odpowiedzią na starzenie się społeczeństwa w XXI wieku. Acta Univ. Lodz. Folia Oeconomica 2015, 4/315, 71-90. [CrossRef]

28. Brecht, S.B. Analyzing Seniors' Housing Markets; Urban Land Institute: Washington, DC, USA, 2002; ISBN 0874208858.

29. Anarde, S. Home sweet home: Aging in place in rural America. Generations 2019, 43, 17-23.

30. Ismail, H.; Halil, F.M.; Abidin, A.W.Z.; Hasim, M.S. The Elderly (Senior) Housing Preferences among Generations in Malaysia. Environ. Proc. J. 2020, 5, 145-154. [CrossRef]

31. Ossokina, I.V.; Arentze, T.A.; van Gameren, D.; van den Heuvel, D. Best living concepts for elderly homeowners: Combining a stated choice experiment with architectural design. J. Hous. Built Environ. 2019. [CrossRef]

32. Filipovič Hrast, M.; Sendi, R.; Hlebec, V.; Kerbler, B. Moving House and Housing Preferences in Older Age in Slovenia. Hous. Theory Soc. 2019, 36, 76-91. [CrossRef]

33. Kramar, C.; Pfaffenbach, C. Should I stay or should I go? Housing preferences upon retirement in Germany. J. Hous. BUILT Environ. 2016, 31, 239-256. [CrossRef] 
34. Hillcoat-Nalletamby, S.; Ogg, J.; Renaut, S.; Bonvalet, C. Ageing Populations and Housing Needs: Comparing Strategic Policy Discourses in France and England. Soc. Policy Adm. 2010, 44, 808-826. [CrossRef]

35. Pedersen, M. Senior Co-Housing Communities in Denmark. J. Hous. Elderly 2015, 29, 126-145. [CrossRef]

36. Gu, T.; Yuan, J.; Li, L.; Shao, Q.; Zheng, C. Demand for community-based care services and its influencing factors among the elderly in affordable housing communities: A case study in Nanjing City. BMC Health Serv. Res. 2020, 20, 241. [CrossRef]

37. Van Hoof, J.; Schellen, L.; Soebarto, V.; Wong, J.K.W.; Kazak, J.K. Ten questions concerning thermal comfort and ageing. Build. Environ. 2017, 120, 123-133. [CrossRef]

38. Hwang, E.; Parrott, K.; Brossoie, N. Research on Housing for Older Adults: 2001 to 2018. Fam. Consum. Sci. Res. J. 2019, 47, 200-219. [CrossRef]

39. Carroll, J.; Qualls, S.H. Moving into senior housing: Adapting the old, embracing the new. Generations 2014, 38, 42-47.

40. Glasby, J.; Allen, K.; Robinson, S. "A game of two halves?" Understanding the process and outcomes of English care home closures: Qualitative and quantitative perspectives. Soc. Policy Adm. 2019, 53, 78-98. [CrossRef]

41. Felix, J. Silver economy: Opportunities and challenges to Brazil adopt the European Union's strategy. Innovation 2016, 29, 115-133. [CrossRef]

42. Kohlbacher, F.; Herstatt, C. The Silver Market Phenomenon: Business Opportunities in an Era of Demographic Change; Springer: Berlin/Heidelberg, Germany, 2008; ISBN 9783540753308.

43. Krzyminiewska, G. Ethical dilemmas of the silver economy. Ekon. i Prawo 2020, 19, 61. [CrossRef]

44. Bran, F.; Popescu, M.; Stanciu, P. Perspectives of Silver Economy in European Union. Rev. Manag. Comp. International 2016, 17, 130-135.

45. Klimczuk, A. Economic Foundations for Creative Ageing Policy. Volume II: Putting Theory into Practice; Palgrave Macmillan: New York, NY, USA, 2017; ISBN 9781137535238.

46. Malik, K.; Mikolajczak, E. Senior housing universal design as a development factor of sustainable-oriented economy. Sustainability 2019, 11, 7093. [CrossRef]

47. Drum, J.L.; Medvene, L.J. The social convoys of affordable senior housing residents: Fellow residents and “Time Left. " Educ. Gerontol. 2017, 43, 540-551. [CrossRef]

48. Gunderson Hunt, K. New Senior Housing Market. J. Prop. Manag. 2012, 77, 18-22.

49. Hogan, J.J. The Senior Housing Industry: Market Characterstics and Market Data. Apprais. J. 1999, 67, 199.

50. Perry, T.E.; Wintermute, T.; Carney, B.C.; Leach, D.E.; Sanford, C.; Quist, L. Senior housing at a crossroads: A case study of a university/community partnership in Detroit, Michigan. Traumatology 2015, 21, 244-250. [CrossRef]

51. Dragan, A. Starzenie się społeczeństwa poslkiego i jego skutki. In Opracowania Tematyczne OT-601. Available online: https://www.senat.gov.pl/gfx/senat/pl/senatopracowania/15/plik/ot-601.pdf (accessed on 21 April 2020).

52. Lynn, D.; Wang, T. The U.S. Senior Housing Opportunity: Investment Strategies. Real Estate Issues 2008, 33, 33-51.

53. Gradzik, B. Senior Housing Vs Senior Financial Possibilities. Społeczeństwo I Ekon. 2017, 2, 71-82. [CrossRef]

54. Winke, T. Later life moves and movers in Germany: An expanded typology. Comp. Popul. Stud. 2017, 42, 3-24. [CrossRef]

55. Tanaś, J.; Trojanek, M.; Trojanek, R. Seniors' revealed preferences in the housing market in Poznań. Econ. Sociol. 2019, 12, 353-365. [CrossRef]

(C) 2020 by the authors. Licensee MDPI, Basel, Switzerland. This article is an open access article distributed under the terms and conditions of the Creative Commons Attribution (CC BY) license (http://creativecommons.org/licenses/by/4.0/). 